Research Article

\title{
The Effects of Cryogenic Process on the AISI M2 Punch Materials and on the Hole Edge Geometry of the DIN EN 10111-98 Sheet Metal Control Arm Parts
}

\author{
Yusuf Arslan \\ Department of Mechanical and Metal Technology, Vocational School of Duzce University, Duzce 81010, Turkey \\ Correspondence should be addressed to Yusuf Arslan; yusufarslan@duzce.edu.tr
}

Received 25 September 2019; Revised 7 December 2019; Accepted 2 January 2020; Published 22 January 2020

Academic Editor: Raffaele Sepe

Copyright (C) 2020 Yusuf Arslan. This is an open access article distributed under the Creative Commons Attribution License, which permits unrestricted use, distribution, and reproduction in any medium, provided the original work is properly cited.

\begin{abstract}
In this study, not only the effects of cryogenic processing on the wear of AISI M2 punches but also the effects of punch wear on the hole edge geometry of DIN EN 10111-98 sheet metal control arm parts were investigated. The hole geometry changes are generally associated with punch wear and process parameters. Piercing operations were performed using eccentric press on 2.5-mm-thick sheet metal control arm parts with circular and slot AISI M2 tool steel punches. The punches were traditionally heat treated. The others were cryogenically treated at $-145^{\circ} \mathrm{C}$ in addition to the conventional heat treatment. Weight losses were measured for punch wear assessments; furthermore, SEM and OM images were analyzed. The hole edge geometries of the selected parts were measured with a contour measuring machine in the specified number of blanks. So, no damage was done to the products for measurements. The cryogenic process resulted in a significantly low amount of retained austenite and caused uniformly distributed thin carbide precipitates. Reduction of retained austenite and formation of fine carbide particles led to increase in hardness values. It was found that untreated circular punch wear weight losses were approximately $40 \%$ higher than those of cryogenically treated samples. The untreated slot punch change rate was about $106 \%$ higher than that of the cryogenically treated samples. The wear process during the punching was faster and greater for the untreated punches. Fatigue microcracks were more common at the cutting edge of the untreated punches. However, abrasive wear was generally observed in cryogenically treated punches. The edge geometry values in the circular holes were at least two times higher than those in the slot holes of untreated samples. At the end of the industrial piercing process, it was determined that the M2 tool steel punch wear rates were decreased by cryogenic treatment, and the size changes of the hole geometry of the punches of the DIN EN 10111-98 control arm parts were more economic and with a better quality.
\end{abstract}

\section{Introduction}

The suspension system carries the vehicle body and allows them to travel comfortably without transmitting all forces to the driver and passengers. It is also used to support its weight in changing road conditions. It consists of several parts and components. Sheet metal control arm is a significant component. The part is located between the wheel and the chassis of the vehicle [1]. Although composites are important today, most of the components are made of metals and alloys. Although there are many different metals and alloys that can be used, the most common ones are steel and aluminium because of their mechanical properties and price.
However, titanium and stainless steel can be used in important designs. Because of the importance of sheet metal control arm, they are usually made of forged steel and sheet metal $[2,3]$.

In the production of sectors such as automotive and house goods, forming with die is an important part. Developments in die design and manufacturing have not only increased their lifetime but also increased the quality of punching and cutting by enabling a more precise and cost-effective production process. The cutting process during sheet metal piercing causes plastic deformation, cutting, and fracture stages. The punching parameters of the press machine, type, thickness, die 
clearance, and piercing forces of the workpiece were found to affect the hole edge geometry in previous studies $[4,5]$.

Long-lasting dies and punches, more strokes, and fewer wastes have to be produced in order to compete in today's markets. The quality of the punched parts is generally assessed by criteria such as bore edge geometry and burr height. These criteria are influenced by machining parameters, punch properties, and punch wear $[6,7]$. The punch material and geometry can be held responsible for the rapid and excessive wear of the punch bits. Excessive stresses occur because of the mechanical properties of the workpiece and punch material. Severe friction during cutting constitutes major wear events. These tribological phenomena can be explained as adhesion, transfer between friction elements, and fatiguerelated microfractures. Punches and dies need to be replaced in optimum time to maintain hole quality. If the wear punches do not change at the appropriate time, they may adversely affect the hole geometry and may cause increased production costs [8]. For better results, the punching and cutting parameters of the punch and workpiece materials must be selected appropriately. In industrial applications, much work has been done, such as tool life, wear, cutting clearance, and material thickness, except for examining the hole geometry of the products $[9,10]$.

Conventional heat treatments are carried out to increase the production speed of the die components made from tool steels such as high-speed steel and to increase the service life under fluctuating loads. However, as a result of these processes up to room temperature, there is still a considerable amount of retained austenite in the structure of the die materials. Although mechanical properties and wear resistance increased by heat treatment, this microstructure, which is softer during production, adversely affects wear resistance during production. In the recent studies, it has been shown that the retained austenite in the microstructure after the traditional heat treatment of the tool steels is reduced by subzero operations, and the wear resistance is increased [10-15].

Wear problems of high-alloy steels used in important industries such as molding have been reduced by cryogenic processing. In the literature, it has been reported that the cryogenic process has a significant contribution in comparison of the wear performance of conventional heat treatment and cryogenically treated counterparts [16]. At the end of the cryogenic process, very fine carbide precipitations occurred, and hardness increases with a smooth distribution in the microstructure of tool steel, which retained austenite transformed into martensite structure. These improvements in tool steel have led to increase in friction resistance. In contrast to the coating process, the cryogenic process is an additional process of fine and dense carbide-forming heat treatment, which is uniformly distributed in the matrix structure which acts to the barriers to the dislocation movements [17-19]. The cryogenic process, which is once performed and low cost, is usually carried out at certain times (usually $24-36$ hours). General process application temperatures varies from $-80^{\circ} \mathrm{C}$ to $-193^{\circ} \mathrm{C}$ with a slow cooling speed (generally 2.5 to $5^{\circ} \mathrm{C} / \mathrm{min}$ ). It is brought to ambient temperature at gradually increasing temperatures to avoid thermal shocks. It has been observed that the cryogenic process affects the performance increase in many steel materials, especially high-alloy steels. Studies have shown that the reasons for the increase in performance are changes in microstructures and increase in mechanical properties [20-24].

There are many studies on machining and cutting tools related to the effect of cryogenic processing. These studies are generally concentrated on high-alloy steels and tool steels $[12,13]$. However, in industrial applications, no research has been carried out on the DIN EN 10111-98 sheet metal controls arms of cryogenically treated AISI M2 high-speed tool steel punches. Hence, the focus of this study is to investigate the influences of cryogenic treatment on the performance of the M2 tool steel punches used for piercing on the DIN EN 10111-98 sheet metal control arms of automotives in terms of punch wear and hole edge geometry in industrial applications.

\section{Materials and Methods}

Typical metal control arm parts are shown in Figure 1. Workpiece materials were produced of $2.5-\mathrm{mm}$-thick DIN EN 10111-98 steel sheets. The chemical content and some mechanical values of sheet metal control arm (as provided by the supplier) are presented in Tables 1 and 2.

The piercing processes were carried out using a 125-toncapacity press machine with 60 strokes per minute. The piercing operations were performed under dry conditions in this industrial application. The cutting clearance used was $6 \%$ of the sheet metal control arm part thickness. The parts were measured at 6,000th, 12,540th, and 26,500th strokes.

The punches were designed to dimensions of $10.5 \times 8.5 \times 100 \mathrm{~mm}$ (slot punch) and $\varnothing 6.2 \times 100 \mathrm{~mm}$ (circular punch) as shown in Figure 2. The punch materials were the AISI M2 tool steel. The chemical content and some mechanical values of punches (as provided by the tool supplier) are presented in Tables 3 and 4.

In this study, punch tools were exposed to cryogenic processing (CT) after conventional heat treatment (HT). The HT of the M2 tool steel involved hardening and tempering. Also, the CT for the M2 steel involved both hardening and cryogenic treatment before annealing (Figure 3).

The HT of M2 tool steels was carried out with 4 bar nitrogen in the vacuum heat treatment furnace (Figure 3 ). The vacuum method is a common process used in the industry. To eliminate the harmful effects of the gases in the air, hardening was conducted in a vacuum atmosphere $[25,26]$. In the CT operation, HT samples were gradually reduced to $-145^{\circ} \mathrm{C}$ at a cooling rate of about $5^{\circ} \mathrm{C}$ per minute. It was kept at this temperature for 36 hours. Then, the temperature was raised to room temperature at the same speed, and tempering operations were performed. The heat treatment schema of AISI M2 punches is shown in Figure 3.

Macrohardness measurements were performed using the HOYTOM 1003 test machine for Rockwell hardness values, 

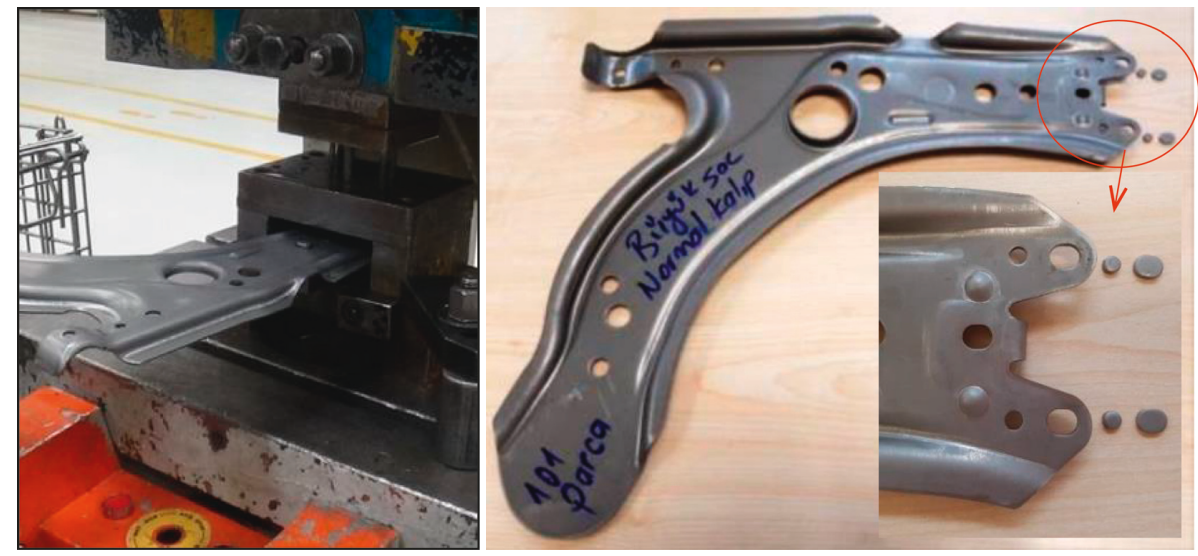

FIGURE 1: Die application and piercing pattern for slot and circular parts of the control arm.

TABLE 1: Chemical composition of DIN EN 10111-98 sheet metal steel (by the sheet metal supplier).

\begin{tabular}{ccccccccc}
\hline Elements (wt.\%) & $\mathrm{C}$ & $\mathrm{Mn}$ & $\mathrm{Al}$ & $\mathrm{S}$ & $\mathrm{P}$ & $\mathrm{Si}$ & $\mathrm{Cr}$ & $\mathrm{Ni}$ \\
\hline & 0.054 & 0.246 & 0.051 & 0.0071 & 0.0047 & 0.002 & 0.011 & 0.037 \\
\hline
\end{tabular}

TABLE 2: Mechanical properties of DIN EN 10111-98 sheet metal steel (by the sheet metal supplier).

\begin{tabular}{lcccc}
\hline Tensile strength $(\mathrm{MPa})$ & Compressive yield strength $\left(\right.$ at $\left.149^{\circ} \mathrm{C}\right)(\mathrm{MPa})$ & Hardness $\left(\mathrm{H}_{\mathrm{B}}\right)$ & Density $\left(\mathrm{gr} / \mathrm{cm}^{3}\right)$ \\
\hline 950 & 250 & 225 & 8.20 \\
\hline
\end{tabular}

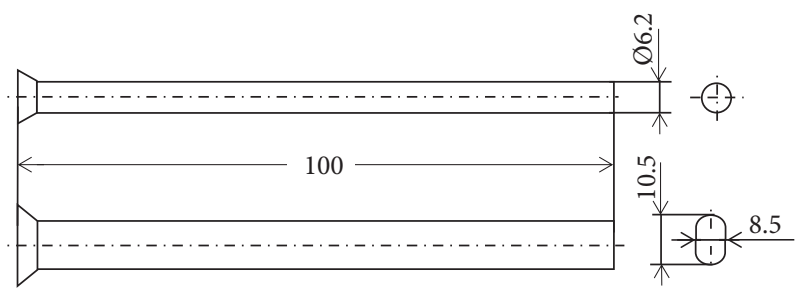

FIGURe 2: AISI M2 tool steel circular and slot punches (DIN 9861).

according to ASTM E18. The main load $1.5 \mathrm{kN}$ and 20 seconds was applied after a preload of $0.1 \mathrm{kN}$. The average of five measurement values was used as the hardness value.

For microstructural studies, AISI M2 samples were polished between 80 and 1200 mesh SiC grinding papers. After polishing with diamond polishing solution, it was etched 3 times for 10-20 seconds with 2\% Nital. Microstructural examinations were performed with FEI Quanto FEG 250 scanning electron microscope (SEM). X-ray diffraction (XRD) analyses were made to determine the variants in the microstructure caused by cryogenic treatment. The retained austenite analyses were made according to ASTM standard E975-13.

Weight loss of the punches was measured on the sensitive scale (ELE L 200S Sartorius Laboratory with a sensitivity of $1 \times 10^{-3} \mathrm{~g}$ ). The weight losses of the punches were measured at 6,000 th, 12,540 th, and 26,500th strokes. This process was repeated 3 times and averaged. Also, at the end of all stages, the face wear of the punches were defined by Optical Dino-Lite Digital Microscope (OM) Pro2 (with a sensitivity of $1 \times 10^{-3} \mathrm{~mm}$ ) and SEM images.
For the measurement of the cut surface of the holes, MarSurf CD 120 contour measuring machine with a sensitivity of $1 \times 10^{-3} \mathrm{~mm}$ was used. Thus, no damage was done to the control arm parts for measurements. Typical outputs of contour measuring machine are shown in Figure 4. For the measurements, 100 control arm parts were taken at the end of each stroke for four different regions of the holes. The average of the recorded $\left(s_{\mathrm{d}}\right.$ smooth-sheared value, $f_{\mathrm{d}}$ fracture value, and $h_{\mathrm{b}}$ burr value) values was obtained. Rollover depth $\left(r_{\mathrm{d}}\right)$ was calculated using read values and $\left(t_{\mathrm{s}}\right)$ sheet thickness from the following equation (Figure 4 ):

$$
r_{\mathrm{d}}=t_{\mathrm{s}}-\left[\left(s_{\mathrm{d}}+f_{\mathrm{d}}\right)-h_{\mathrm{d}}\right] .
$$

For example, $r_{\mathrm{d}}=2.5-[(1.488+0.766)-0.043]=0.289 \mathrm{~mm}$ (from Figure 4 and equation (1)).

\section{Results and Discussion}

Most researchers found that the holding time for the samples in the cryogenic treatment procedure had influential effects on material properties such as hardness and microstructure (Figure 5). Figures 6(a) and 6(b) show the effect of cryogenic treatment on the microstructure. It is clearly seen that uniformly and finely distributed primary (PC) and secondary carbide (SC)-based particles are present in the microstructure. Also, it was observed that both primary and secondary particles were more pronounced than conventional counterparts. Similarly, newly formed carbides in the microstructure and a more uniform distribution were reported in the literature $[14,15]$. These developments in the microstructure due to the cryogenic processing resulted in 
TABLE 3: Chemical content of M2 steel (by the tool supplier).

\begin{tabular}{ccccccccccc}
\hline Elements (wt.\%) & $\mathrm{C}$ & $\mathrm{W}$ & $\mathrm{Mo}$ & $\mathrm{Cr}$ & $\mathrm{Mn}$ & $\mathrm{Si}$ & $\mathrm{P}$ & $\mathrm{V}$ & $\mathrm{S}$ \\
\hline & 0.890 & 6.150 & 4.750 & 4.060 & 0.350 & 0.360 & 0.024 & 1.880 & 0.006 \\
\hline
\end{tabular}

TABLE 4: The strength values of M2 steel (by the tool supplier).

\begin{tabular}{lccc}
\hline Tensile strength $(\mathrm{MPa})$ & Compressive yield strength $\left(\right.$ at $\left.149^{\circ} \mathrm{C}\right)(\mathrm{MPa})$ & Hardness $\left(\mathrm{H}_{\mathrm{B}}\right)$ & $\mathrm{Density}\left(\mathrm{gr} / \mathrm{cm}^{3}\right)$ \\
\hline 950 & 250 & 225 & 8.20 \\
\hline
\end{tabular}

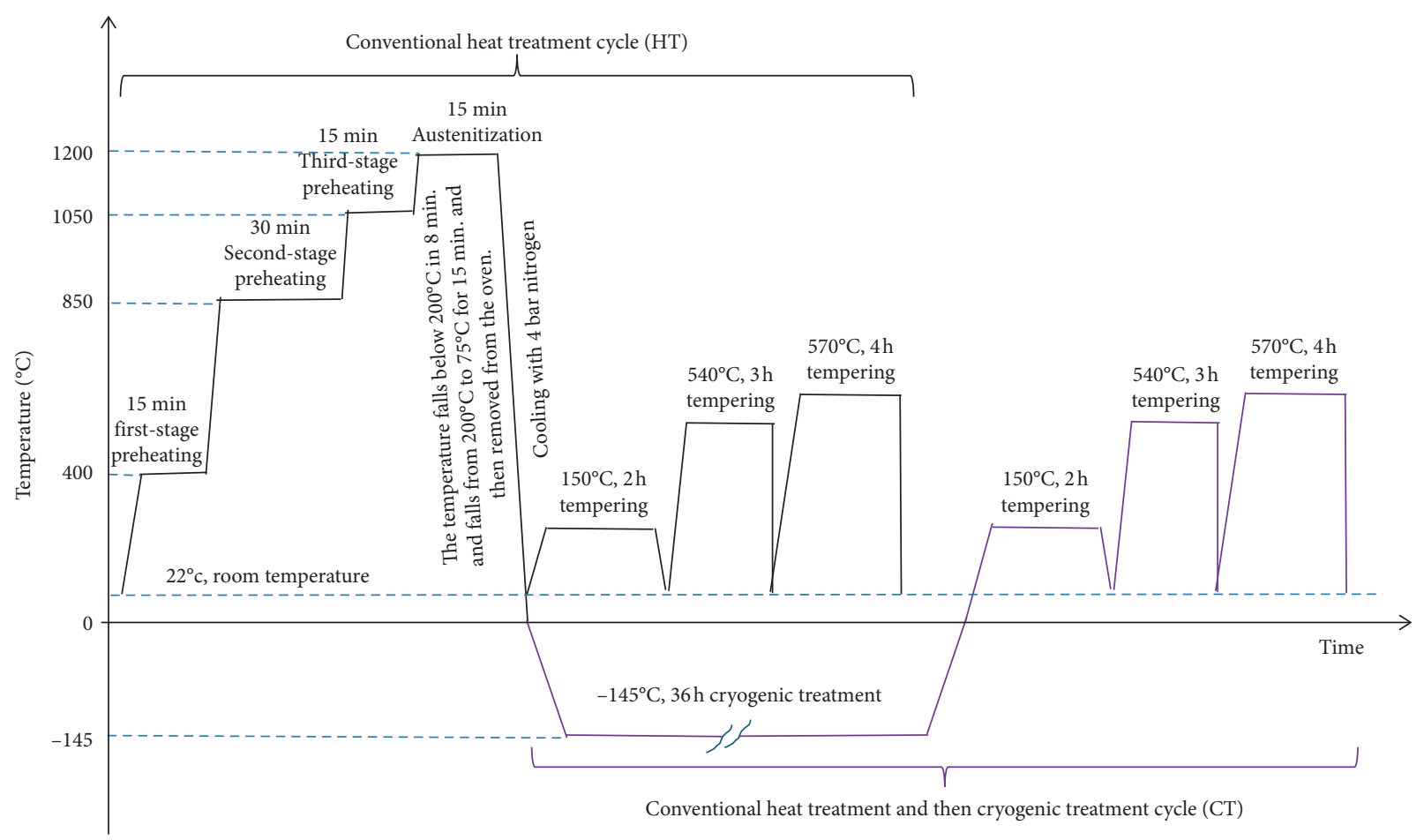

Figure 3: Heat treatment schema of AISI M2 punches.

an increase in the hardness and mechanical response of materials [27, 28]. Molinari et al. studied AISI M2 and H13 tool steels and found that hardness values increased about $3 \%$ to $5.8 \%$ times compared with counterparts [29]. In many studies related to cryogenic processing, it has been reported that the microstructure of the steels forms more intense secondary carbides $[12,13,30,31]$.

The results of XRD analysis according to ASTM standard E975-13 for determining the amount of retained austenite of the M2 tool steel after cryogenic processing are given in Figure 7 . When the results in the figure were compared, it was seen that the quantity of retained austenite volume by the cryogenic treatment was significantly reduced to around $4.5 \%$ compared with $22 \%$ in the HT sample. The results showed that the cryogenic process of the AISI M2 tool steel caused a significant change in the microstructure. Studies in the literature have reported that change in microstructure by the cryogenic process positively affects the wear resistance of the samples. Most retained austenite provides martensite transformation and new carbide formation [32, 33].
In Figures 8 and 9, the weight loss in the piercing stages for circular and slot punches was examined and evaluated. The circular punch and slot punch, which have been cryogenically treated, have been found to be less worn in all stages of piercing. It was found that HT circular punch wear weight losses were approximately $40 \%$ higher. This rate was about $106 \%$ higher for HT slot punches. The increase in weight loss and induced wear resistance in the HT punches were also reported for the M2 tool steels [10-12].

Typical SEM images of worn surfaces are shown in Figures 10-12. The worn surfaces were found to be greater and more severe in HT punches than CT counterparts. Fatigue microcracks were more pronounced at the cutting edge of the HT punch (Figures 11 and 12). These fatigue cracks significantly affect the main crack initiation and crack propagation [34-36]. The abrasive wear was generally observed in CT punches. Additionally, more microcracks and fatigue wear were observed not only in the circular HT punch but also in the circular zone of slot HT punch (Figures 11 and 12). 


\begin{tabular}{|ll|}
\hline Ölçüm donami: & MarTalk \\
Sürücü ünitesi: & Drive unit.CD 120 \\
Alma: & PCV $350 \times 33 \mathrm{~mm} 6581$ \\
Lt: & $3.21 \mathrm{~mm}$ \\
Ls: &,--- \\
VB: & $+/-25861.3 \mu \mathrm{m}$ \\
Vt: & $1.00 \mathrm{~mm} / \mathrm{s}$ \\
Noktalar: & 3207 \\
\hline
\end{tabular}

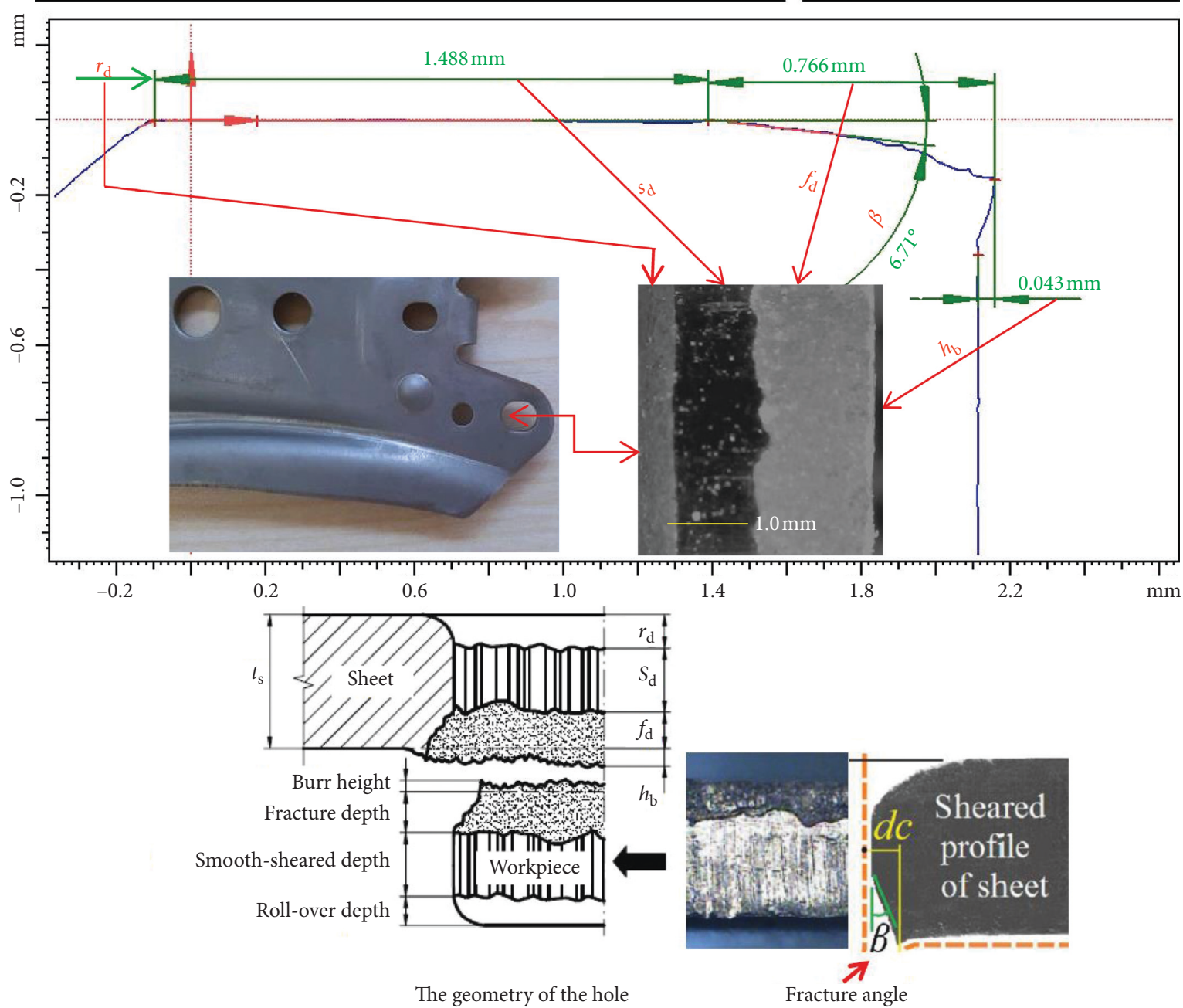

FIgURE 4: Outputs of contour measuring machine and the geometry of the hole [5].

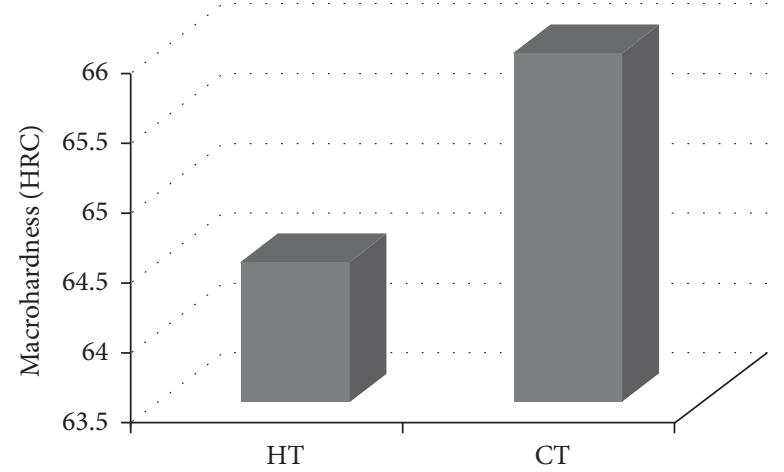

FIgURE 5: Macrohardness test results of the AISI M2 tool steel. 


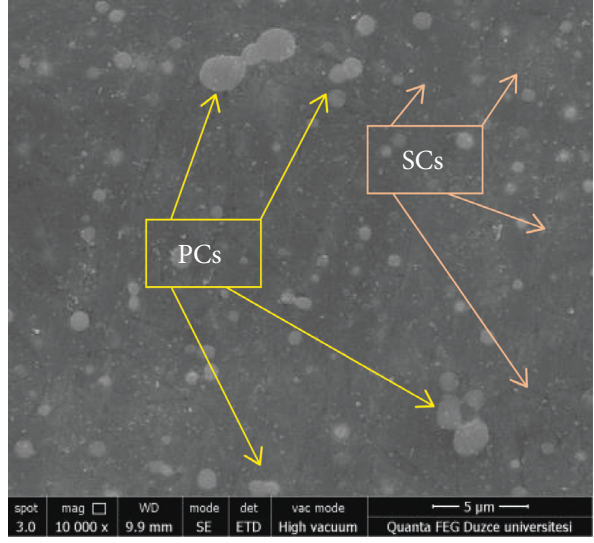

(a)

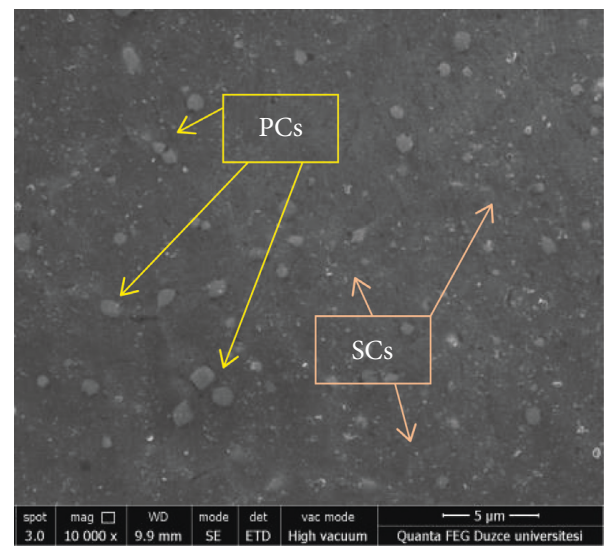

(b)

Figure 6: Microstructure of AISI M2 samples. (a) HT. (b) CT.

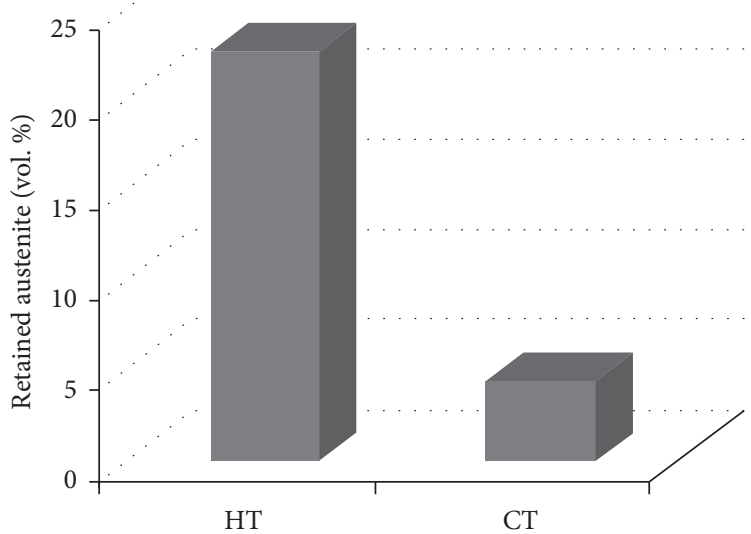

FIgURE 7: Retained austenite of AISI M2 tool steels.

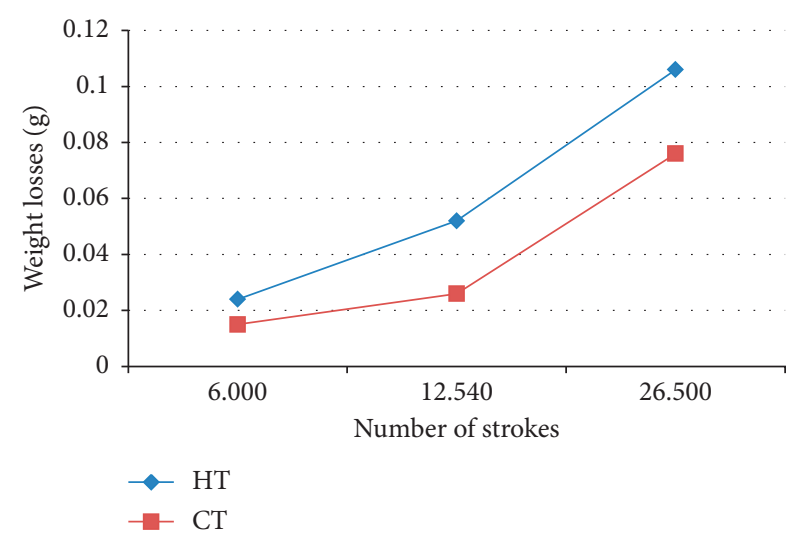

FIGURE 8: Weight loss and number of strokes (circular punch $\varnothing 6.2 \times 100 \mathrm{~mm}$ in diameter).

The cryogenically treated M2 punches showed improvements in microstructure and hardness as well as weight loss results. The weight loss of the circular HT punches was about $40 \%$ higher as compared with CT samples. Similarly, the weight loss of slot HT punches was found to be about $106 \%$ higher. Like the results of the cryogenic work done

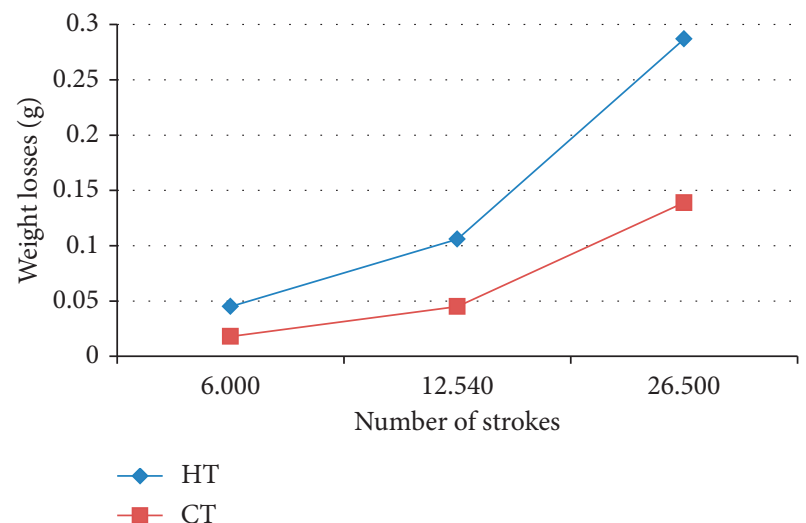

Figure 9: Weight loss and number of strokes (slot punch $10.5 \times 8.5 \times 100 \mathrm{~mm}$ in size).

before, CT punches were less worn and cryogenic treatment had a positive effect on the abrasion resistance of M2 highspeed tool steel $[24,30]$.

The average of the recorded values (each element of the cutting zone defined in Figure 4) was obtained. Rollover depth $\left(r_{\mathrm{d}}\right)$ from equation (1) was calculated and 


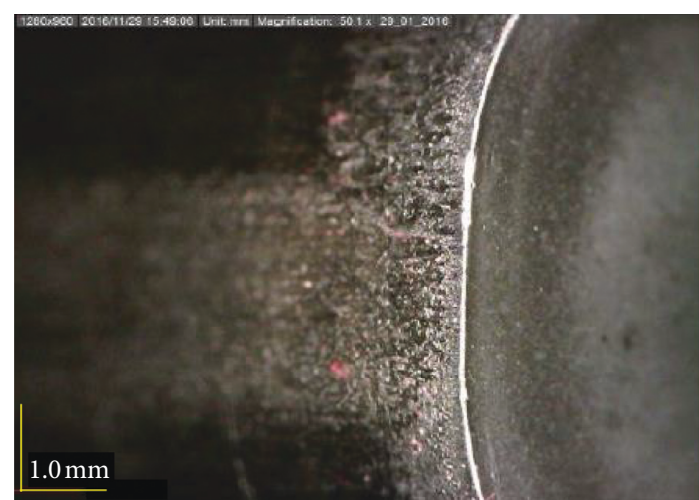

(a)

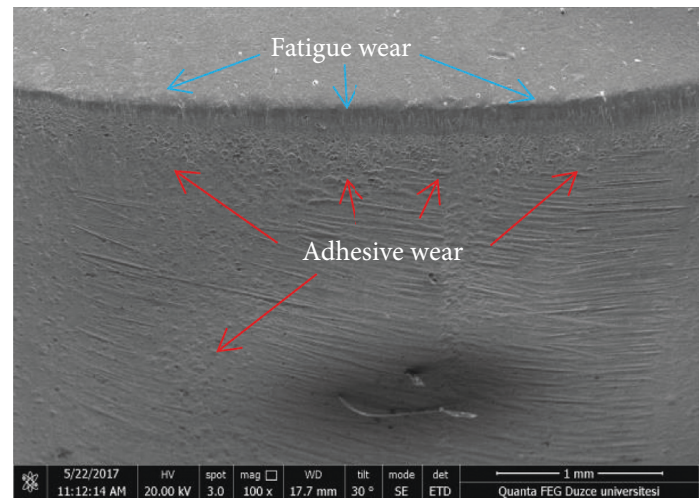

(c)

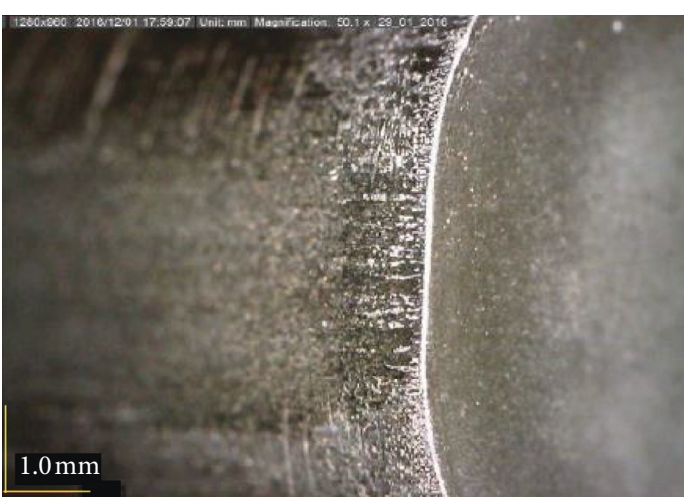

(b)

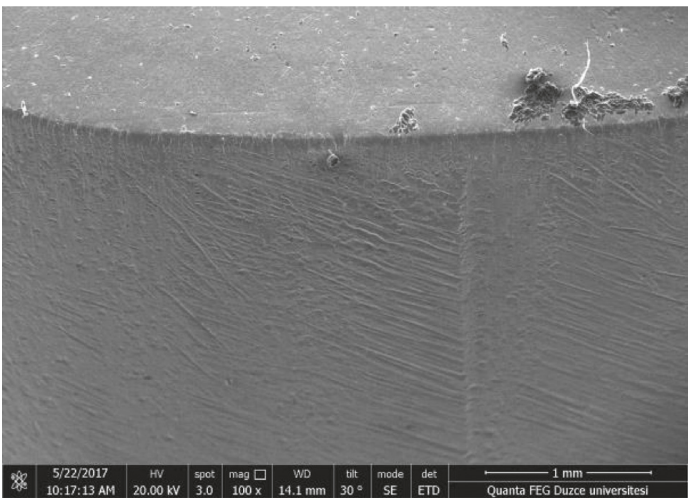

(d)

Figure 10: Edge and face wear of the flat edge of slot punch at the 26.500 strokes (slot punch $10.5 \times 8.5 \times 100 \mathrm{~mm}$ in size). (a) $\mathrm{HT}(\mathrm{OM} \times 50$ ). (b) $\mathrm{CT}(\mathrm{OM} \times 50)$. (c) $\mathrm{HT}(\mathrm{SEM} \times 100)$. (d) $\mathrm{CT}(\mathrm{SEM} \times 100)$.

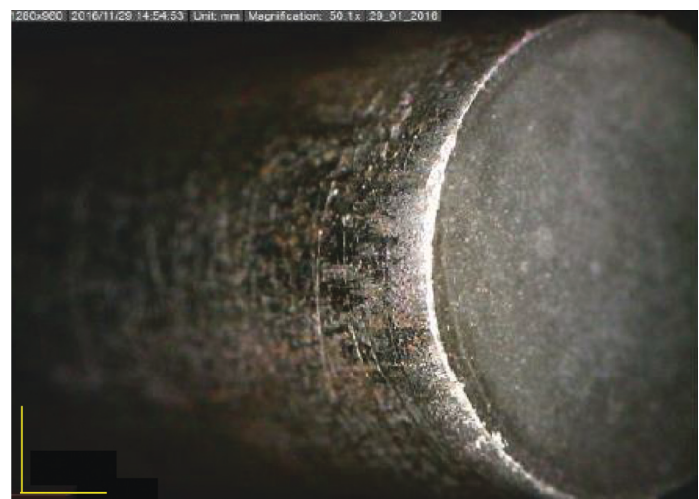

(a)

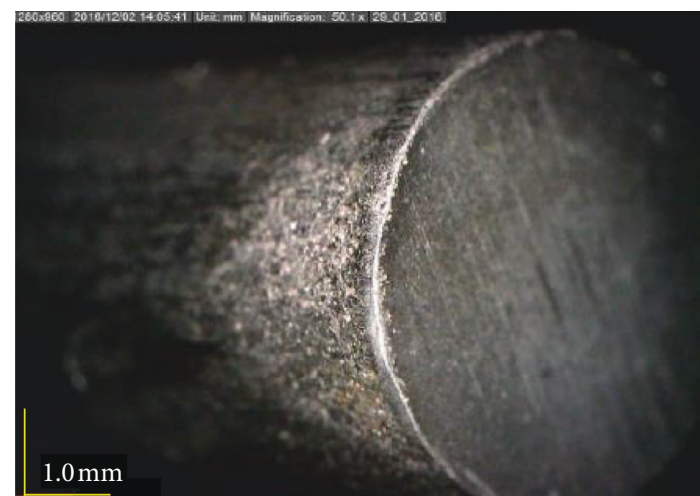

(b)

FIgURe 11: Continued. 


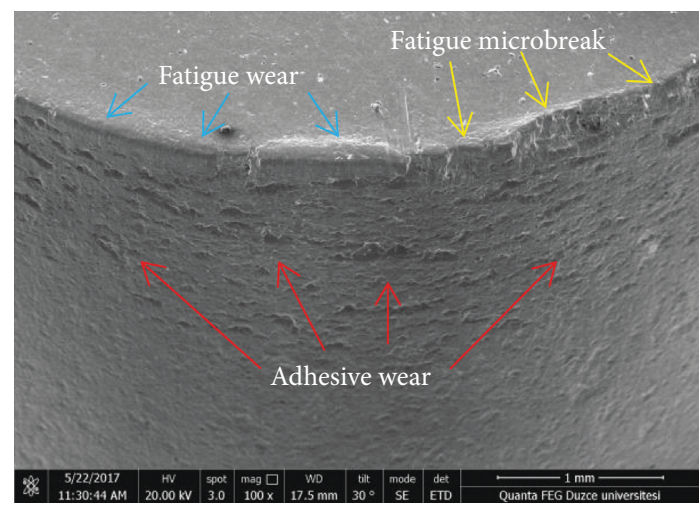

(c)

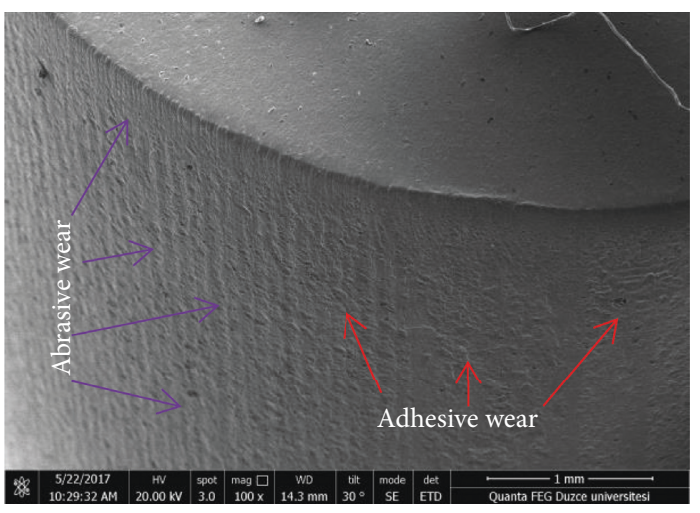

(d)

Figure 11: Edge and face wear of the circular zone of slot punch at the 26.500 strokes (slot punch $10.5 \times 8.5 \times 100 \mathrm{~mm}$ in size). (a) HT $(\mathrm{OM} \times 50)$. (b) $\mathrm{CT}(\mathrm{OM} \times 50)$. (c) $\mathrm{HT}(\mathrm{SEM} \times 100)$. (d) $\mathrm{CT}(\mathrm{SEM} \times 100)$.

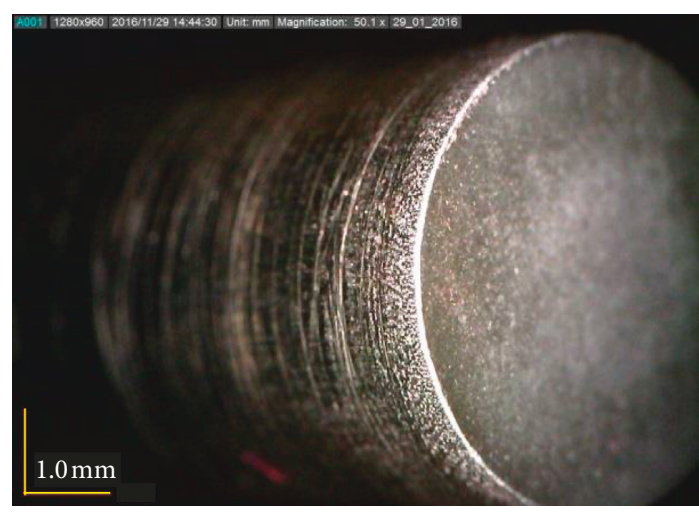

(a)

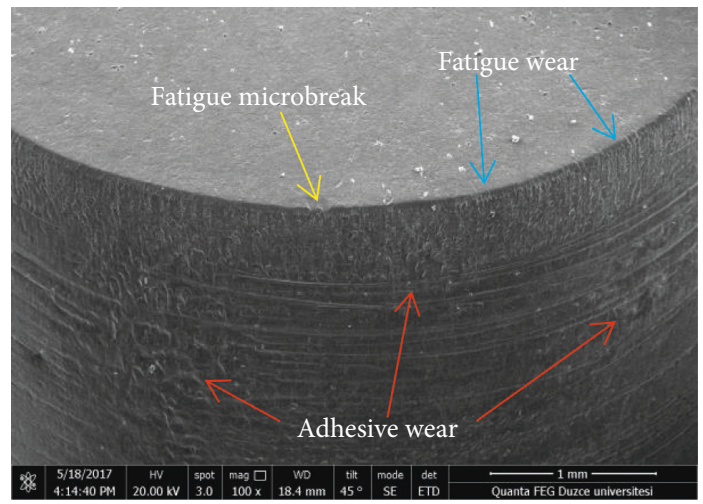

(c)

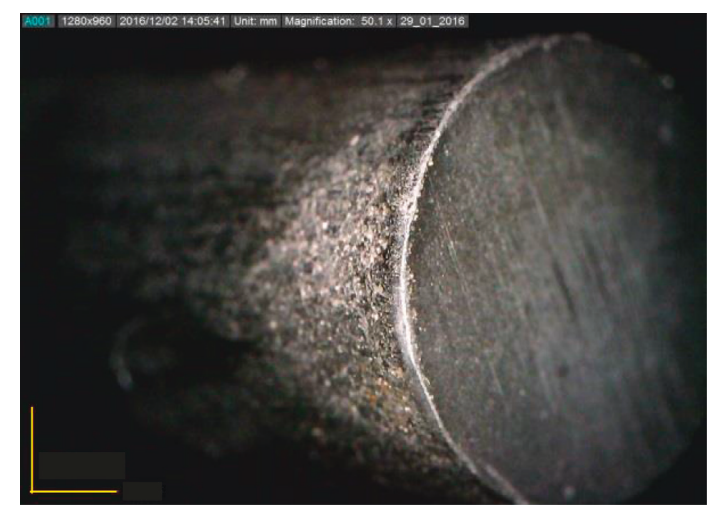

(b)

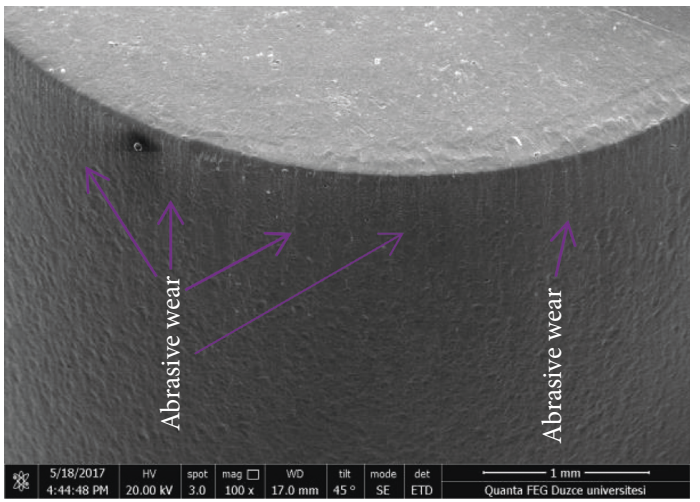

(d)

FIGURE 12: Edge and face wear of the circular punch at the 26.500 strokes (circular punch $\varnothing 6.2 \times 100 \mathrm{~mm}$ in diameter). (a) HT (OM $\times 50)$. (b) $\mathrm{CT}(\mathrm{OM} \times 50)$. (c) HT $(\mathrm{SEM} \times 100)$. (d) CT $(\mathrm{SEM} \times 100)$.

evaluated using output values and $\left(t_{\mathrm{s}}\right)$ sheet thickness. It can be seen that there is an increase in the rollover depth, fracture depth, burr height, and fracture angle values in edge geometry of both slot punch and circular holes but it appears to decrease the value of smooth-sheared depth (Figures 13-15). In the holes produced by the HT slot punch compared with CT, rollover depth, fracture depth, burr height, and fracture angle increased by $4,10,8$, and $15 \%$, respectively, but decreased by $27 \%$ smooth-sheared depth. Besides, comparing the HT circular punch with CT, rollover depth, fracture depth, burr height, and fracture angle increased by $10,19,23$, and $32 \%$, 
HT

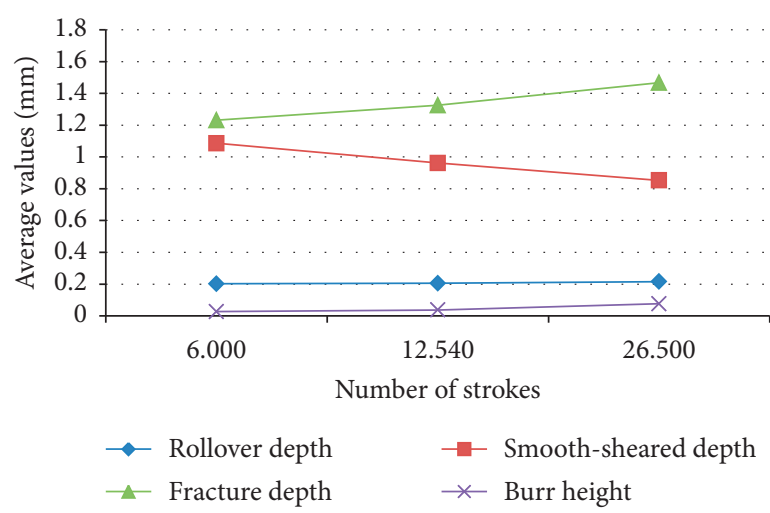

(a)

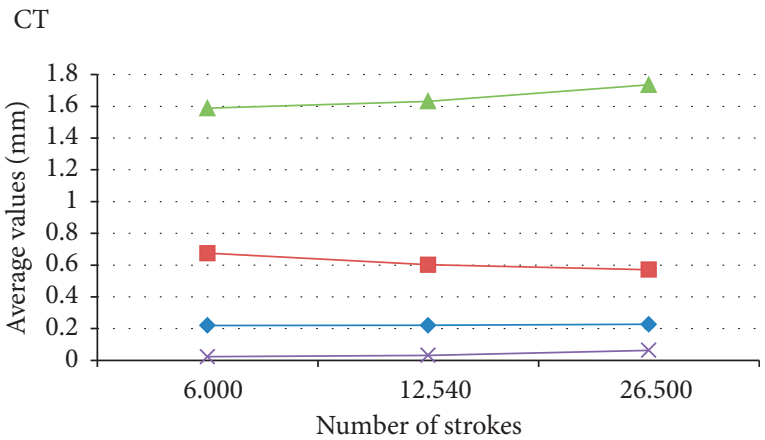

$\rightarrow$ Rollover depth $\quad \rightarrow-$ Smooth-sheared depth

$\rightarrow$ Fracture depth $\quad *$ Burr height

(b)

FIgURE 13: Average values of geometry of the cut surface of the holes of the control arm part (slot hole $10.5 \times 8.5 \mathrm{~mm}$ in size).

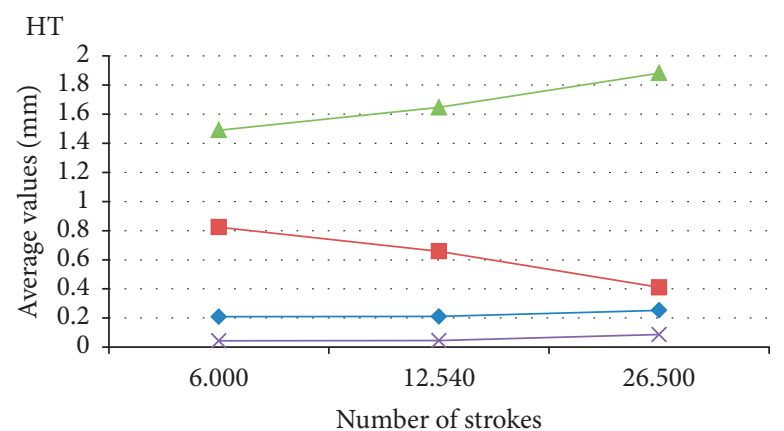

$$
\begin{array}{ll}
\rightarrow \text { Rollover depth } & \rightarrow \text { Smooth-sheared depth } \\
\rightarrow \text { Fracture depth } & \rightarrow \text { Burr height }
\end{array}
$$

(a)

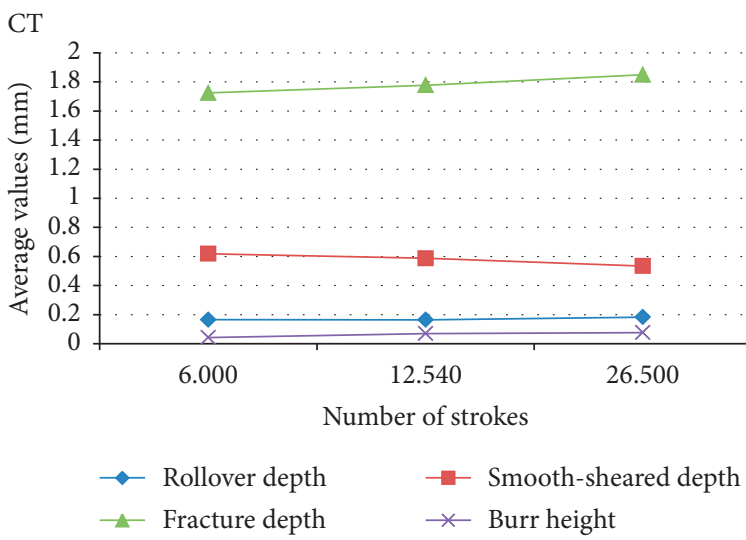

(b)

Figure 14: Average values of geometry of the cut surface of the holes of the control arm part (circular hole, Ø6.2 mm in diameter).
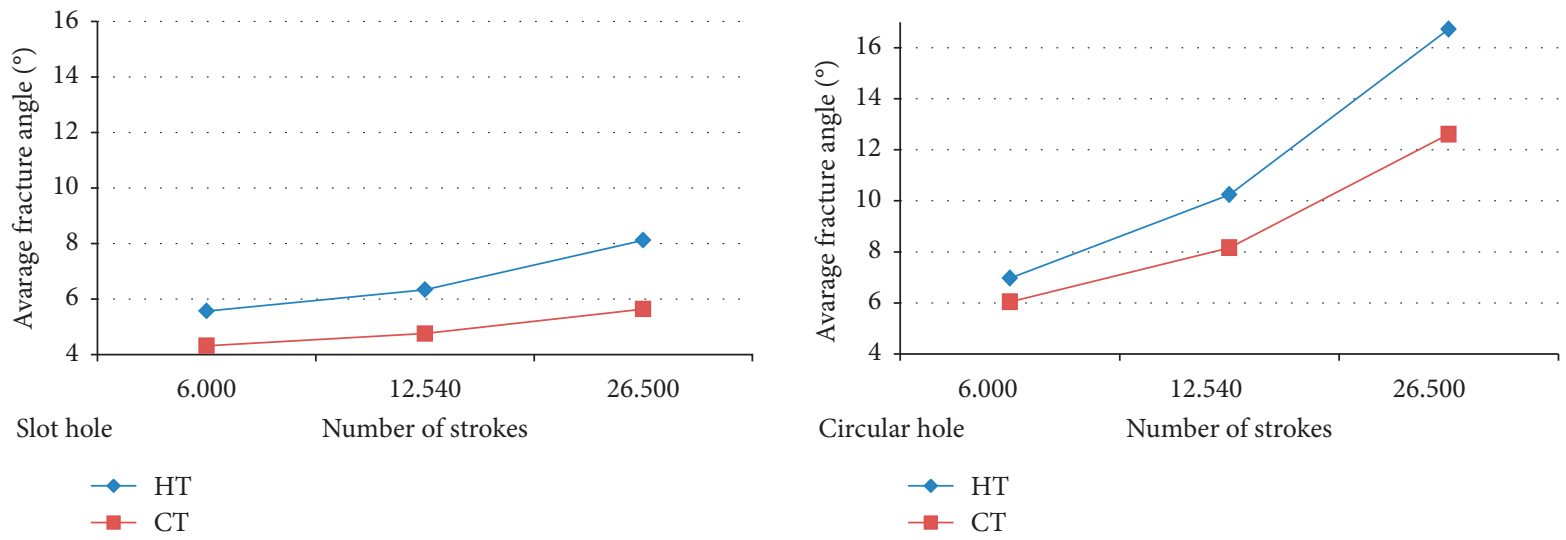

FIGURE 15: Average fracture angle of geometry of the cut surface of the holes of the control arm part (slot hole and circular hole).

respectively, but decreased by $84 \%$ smooth-sheared depth. It can be said that CT process significantly improves physical appearance and surface quality of the products. The important factor in the hole quality of the piercing process is the better hole diameter, circularity, rollover depth, fracture depth, burr height, fracture angle, and smooth-sheared depth control of the samples $[37,38]$. 


\section{Conclusions}

For the M2 tool steel punch and the DIN EN 10111-98 sheet material configuration in industrial application, the following results were reached later.

(1) The cryogenic process resulted in significantly low amount of retained austenite and caused uniformly distributed thin carbide precipitates. Reduction of retained austenite and formation of fine carbide particles led to increase in hardness values. The CT procedure resulted in an improvement approximately $1.5 \mathrm{HRC}$. Also, it can be said that the cryogenic process of the AISI M2 tool steel caused a significant change in microstructure.

(2) It was found that HT circular punch wear weight losses were approximately $40 \%$ higher than CT samples. HT slot punches change rate was about 106\% higher than CT.

(3) Adhesive and abrasive wear on punch cutting surfaces, as well as fatigue wear and microcracks were determined from images. The wear process during the punching was more faster and greater for the HT punches. Fatigue microcracks were more common at the cutting edge of the HT punch. However, abrasive wear was generally observed in CT punches. Additionally, more microcracks and breaks in the circular HT punch were observed.

(4) The edge geometry values in the circular holes were at least two times higher than the slot holes of HT samples.

(5) At the end of the industrial piercing process, it was determined that the M2 tool steel punch wear rates were decreased by cryogenic treatment and the size changes of the hole geometry of the punches of the DIN EN 10111-98 control arm parts were more economic and had better quality.

\section{Data Availability}

The data of the heat treatment, the outputs of contour measuring machine, the macrohardness test results, the SEM images, the XRD results (retained austenite), the weight loss and number of strokes, and the SEM and OM images of the punches used to support the findings of this study are included within the article.

\section{Conflicts of Interest}

The author declares that there are no conflicts of interest.

\section{Acknowledgments}

This study was supported by TUBITAK/TEYDEB 1505 University-Industry Cooperation Research Program under the scope of Project no. 5150012.

\section{References}

[1] D. Kothawale, Y. R. Kharde, and T. Rahata, "Analysis of lower control arm in front suspension system using FEA approach," Analysis, vol. 5, no. 12, pp. 18-23, 2013.

[2] B. Kumar and N. Dayakar, "Design and analysis of sheet metal control arm," International Journal of Science and Research (IJSR), vol. 4, no. 11, pp. 1241-1248, 2015.

[3] M. Sridharan and S. Balamurugan, "Design and analysis of lower control ARM," International Journal of Innovative Research in Science Engineering and Technology, vol. 5, no. 4, 2016.

[4] F. Akyürek, K. Yaman, and Z. Tekiner, "An experimental work on tool wear affected by die clearance and punch hardness," Arabian Journal for Science and Engineering, vol. 42, no. 11, pp. 4683-4692, 2017.

[5] J. Mucha, "An experimental analysis of effects of various material tool's wear on burr during generator sheets blanking," The International Journal of Advanced Manufacturing Technology, vol. 50, no. 5-8, pp. 495-507, 2010.

[6] K. Lawanwong, N. Pornputsiri, and G. Luangsopapun, "An investigation of adhesion wear behavior of tool steel on blanking die," in Proceedings of the 2011 International Conference on Advanced Materials Engineering, vol. 15, pp. 25-30, IACSIT Press, Shenyang, China, 2011.

[7] P. V. P. Marcondes, A. M. Eto, P. A. C. Beltrão, and P. C. Borges, "A smart stamping tool for punching and broaching combination," Journal of Materials Processing Technology, vol. 206, no. 1-3, pp. 184-193, 2008.

[8] M. H. Myint, J. Y. H. Fuh, Y. S. Wong, L. Lu, Z. D. Chen, and C. M. Choy, "Evaluation of wear mechanisms of Y-TZP and tungsten carbide punches," Journal of Materials Processing Technology, vol. 140, no. 1-3, pp. 460-464, 2003.

[9] G. Fang, P. Zeng, and L. Lou, "Finite element simulation of the effect of clearance on the forming quality in the blanking process," Journal of Materials Processing Technology, vol. 122, no. 2-3, pp. 249-254, 2002.

[10] Y. Arslan, I. Uygur, and A. Jazdzewska, "The effect of cryogenic treatment on microstructure and mechanical response of AISI D3 tool steel punches," Journal of Manufacturing Science and Engineering, vol. 137, no. 3, Article ID 034501, 2015.

[11] A. Çiçek, T. Kıvak, I. Uygur, E. Ekici, and Y. Turgut, "Performance of cryogenically treated M35 HSS drills in drilling of austenitic stainless steels," The International Journal of Advanced Manufacturing Technology, vol. 60, no. 1-4, pp. 65-73, 2012.

[12] D. Das, A. K. Dutta, and K. K. Ray, "Influence of varied cryotreatment on the wear behavior of AISI D2 steel," Wear, vol. 266, no. 1-2, pp. 297-309, 2009.

[13] S. Li, Y. Xie, and X. Wu, "Hardness and toughness investigations of deep cryogenic treated cold work die steel," Cryogenics, vol. 50, no. 2, pp. 89-92, 2010.

[14] B. Podgornik, V. Leskovšek, and J. Vižintin, "Influence of deep-cryogenic treatment on tribological properties of $\mathrm{P} / \mathrm{M}$ high-speed steel," Materials and Manufacturing Processes, vol. 24, no. 7-8, pp. 734-738, 2009.

[15] Y. Arslan, U. Seker, Y. Ozcatalbas, and A. Ozdemir, "An investigation of the hole diameter and circulirty on the stainless steel sheet perforated via by deep cryogenically treated cold work tool steel punches," Journal of Engineering Research and Applied Science, vol. 5, no. 1, pp. 378-390, 2016. 
[16] A. Akhbarizadeh, A. Shafyei, and M. A. Golozar, "Effects of cryogenic treatment on wear behavior of D6 tool steel," Materials \& Design, vol. 30, no. 8, pp. 3259-3264, 2009.

[17] D. Das, K. K. Ray, and A. K. Dutta, "Influence of temperature of sub-zero treatments on the wear behaviour of die steel," Wear, vol. 267, no. 9-10, pp. 1361-1370, 2009.

[18] G. Straffelini, G. Bizzotto, and V. Zanon, "Improving the wear resistance of tools for stamping," Wear, vol. 269, no. 9-10, pp. 693-697, 2010.

[19] N. B. Dhokey, A. Hake, S. Kadu, I. Bhoskar, and G. K. Dey, "Influence of cryoprocessing on mechanism of carbide development in cobalt-bearing high-speed steel (M35)," Metallurgical and Materials Transactions A, vol. 45, no. 3, pp. 1508-1516, 2014.

[20] S. S. Gill, J. Singh, R. Singh, and H. Singh, "Metallurgical principles of cryogenically treated tool steels-a review on the current state of science," The International Journal of Advanced Manufacturing Technology, vol. 54, no. 1-4, pp. 59-82, 2011.

[21] M. Preciado, P. M. Bravo, and J. M. Alegre, "Effect of low temperature tempering prior cryogenic treatment on carburized steels," Journal of Materials Processing Technology, vol. 176, no. 1-3, pp. 41-44, 2006.

[22] D. Senthilkumar, I. Rajendran, M. Pellizzari, and J. Siiriainen, "Influence of shallow and deep cryogenic treatment on the residual state of stress of 4140 steel," Journal of Materials Processing Technology, vol. 211, no. 3, pp. 396-401, 2011.

[23] D. Das, A. K. Dutta, and K. K. Ray, "On the enhancement of wear resistance of tool steels by cryogenic treatment," Philosophical Magazine Letters, vol. 88, no. 11, pp. 801-811, 2008.

[24] M. A. Jaswin, D. M. Lal, and A. Rajadurai, "Effect of cryogenic treatment on the microstructure and wear resistance of X45Cr9Si3 and X53Cr22Mn9Ni4N valve steels," Tribology Transactions, vol. 54, no. 3, pp. 341-350, 2011.

[25] Inductotherm Grup, 2018, http://inductotherm.com.tr.

[26] Metalurji, 2018, http://www.metalurji.org.tr/dergi/dergi180/ d180_3136.pdf.

[27] Y. Jiang, D. Chen, Z. Chen, and J. Liu, "Effect of cryogenic treatment on the microstructure and mechanical properties of AZ31 magnesium alloy," Materials and Manufacturing Processes, vol. 25, no. 8, pp. 837-841, 2010.

[28] D. Das, A. K. Dutta, and K. K. Ray, "Sub-zero treatments of AISI D2 steel: part I. Microstructure and hardness," Materials Science and Engineering: A, vol. 527, no. 9, pp. 2182-2193, 2010.

[29] A. Molinari, M. Pellizzari, S. Gialanella, G. Straffelini, and K. H. Stiasny, "Effect of deep cryogenic treatment on the mechanical properties of tool steels," Journal of Materials Processing Technology, vol. 118, no. 1-3, pp. 350-355, 2001.

[30] N. B. Dhokey and S. Nirbhavne, "Dry sliding wear of cryotreated multiple tempered D-3 tool steel," Journal of Materials Processing Technology, vol. 209, no. 3, pp. 1484-1490, 2009.

[31] K. Amini, A. Akhbarizadeh, and S. Javadpour, "Investigating the effect of holding duration on the microstructure of 1.2080 tool steel during the deep cryogenic heat treatment," Vacuum, vol. 86, no. 10, pp. 1534-1540, 2012.

[32] V. Firouzdor, E. Nejati, and F. Khomamizadeh, "Effect of deep cryogenic treatment on wear resistance and tool life of M2 HSS drill," Journal of Materials Processing Technology, vol. 206, no. 1-3, pp. 467-472, 2008.

[33] A. Akhbarizadeh, K. Amini, and S. Javadpour, "Effect of simultaneous magnetic field and deep cryogenic heat treatment on the microstructure of 1.2080 tool steel," Materials \& Design, vol. 35, pp. 484-490, 2012.
[34] I. Uygur, W. J. Evans, M. Bache, and B. Gulenc, "The fatigue behavior of $\mathrm{SiC}$ particulate reinforced 2124 aluminium matrix composites," Metallofizika I Noveishie Tekhnologii, vol. 26, no. 7, pp. 927-939, 2004.

[35] I. Uygur, "Tensile behavior of powder metallurgy processed (ai-Cu-Mg-Mn)/Sicp composites," Iranian Journal of Science \& Technology, Transaction B, vol. 28, no. 2, pp. 239-248, 2004.

[36] I. Uygur, A. Cicek, E. Toklu, R. Kara, and S. Saridemir, "Fatigue life predictions of metal matrix composites using artificial neural networks," Archives of Metallurgy and Materials, vol. 59, no. 1, pp. 97-103, 2014.

[37] O. Çavuşoğlu and H. Gürün, “The relationship of burr height and blanking force with clearance in the blanking process of AA5754 aluminium alloy," Transactions of FAMENA, vol. 41, no. 1, pp. 55-62, 2017.

[38] N. A. Jaafar, A. B. Abdullah, and Z. Samad, "Effect of punching die angular clearance on punched hole quality of S275 mild steel sheet metal," The International Journal of Advanced Manufacturing Technology, vol. 101, no. 5-8, pp. 1553-1563, 2019. 


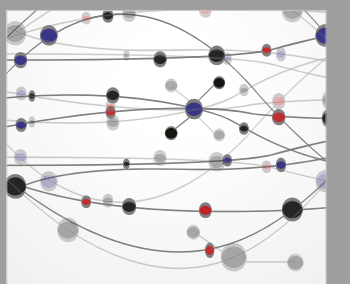

The Scientific World Journal
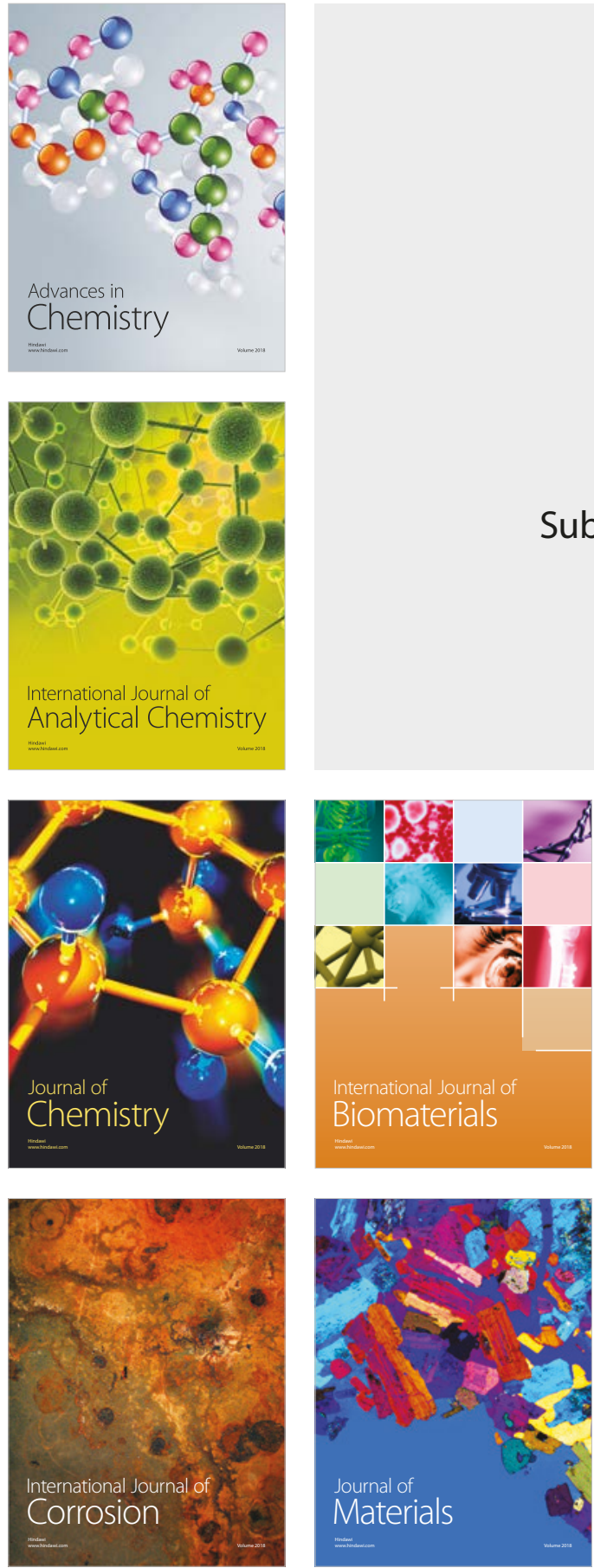

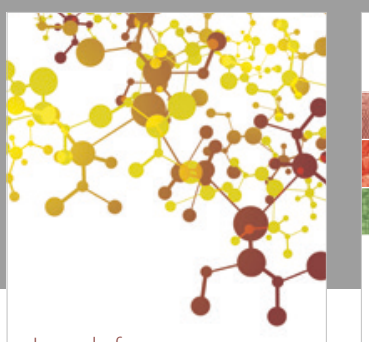

Journal of

Applied Chemistry
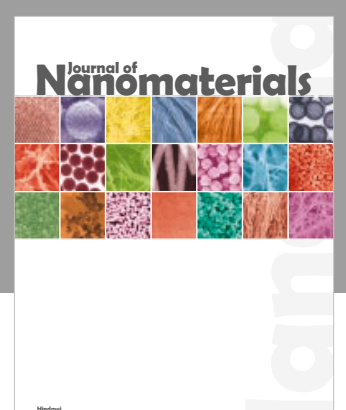

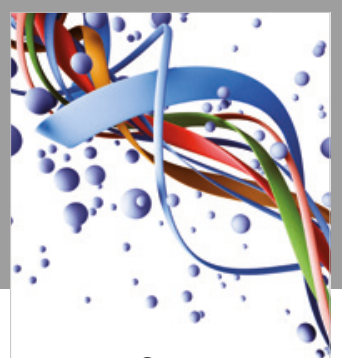

Scientifica

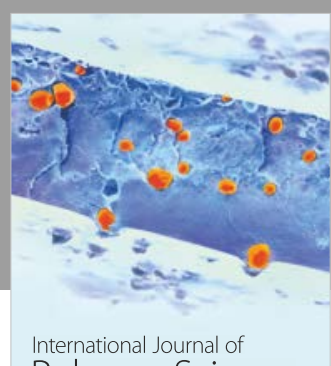

Polymer Science

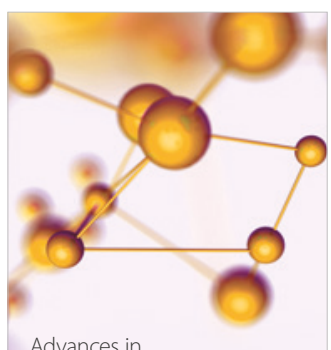

Physical Chemistry
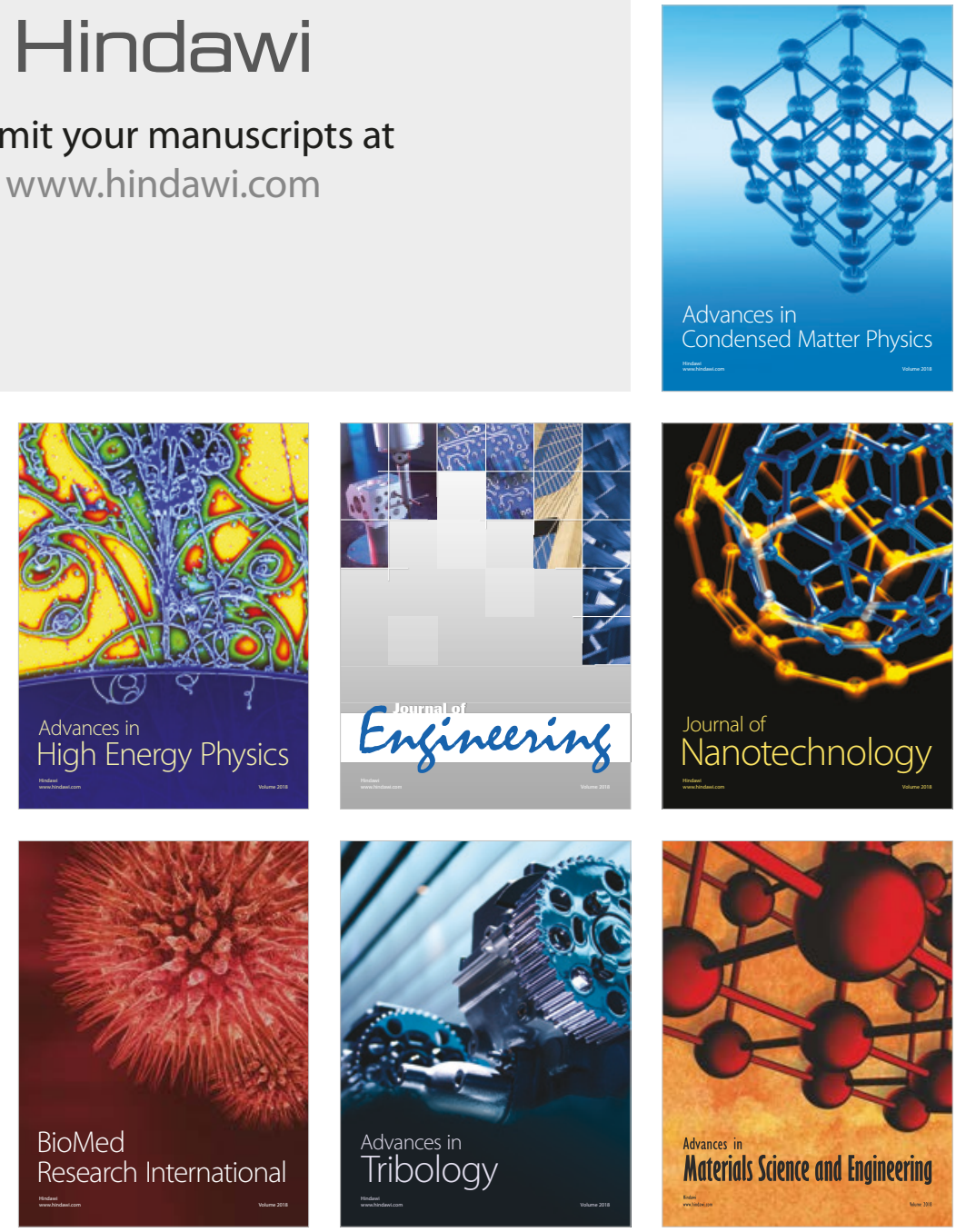